$A$ buffer made by mixing 4 volumes of formic acid with one volume of sodium acetate, each at $0.10 \mathrm{M}$, gives a $\mathrm{pH}$ of 2.0 . This seems most useful for separating AMP of different degrees of sulphation. With veronal buffer at $p \mathrm{H} 8,6$ the technique can be used for tho soparation of non-sulphated glycoproteins and AMP.

The $\Lambda$ MP present in a 1 om square $10 \mu$ section of cartilage are easily detected and separated. As littlo as $0.05 \mu \mathrm{g}$ of standard AMP is easily detected and $0.3 \mu \mathrm{g}$ can be mensured by scanning cleared strips in the Beckman 'Microzone Analytrol'.

Fig. 1 illustrates the separation of hyaluronic acid (HA), chondroitin sulphuric acid (CSA) and heparin from a mixture of standards. The sean is made directly from the clewred strip which was also used as tho "negativo" for tho enlarged print of the separated zones.

This work was supported by U.S. Public Health Service grant $A M 06992$.

ALEX M. SAUNDERS SHARON THOMSEN

Department of Pathology,

Stanford School of Medicine, Palo Alto, California.

${ }^{1}$ von Berlepsch, K. D., k'ed, Proc, 21,171 (1962).

${ }^{3}$ Foster, T. S., and Pearce, R. H., Canad. J. Biochem. Physiol., 39, 1771 (1001).

\$ SalunderB. A. M.. J. Ilistochem. Cytohem., 12, 164 (1064).

\section{Enzymatic Aetion of Lipoglycoprotein Preparations from Sperm-acrosomes on Rabbit Ova}

Tre: curnulus oophorus of rabbit eggs can be dispersed in vitro by suspensions of rabbit spormatozon $a^{1,2}$ or by hyaluronidase ${ }^{3}$, but the corona radiata remains intact. Both the corona and the zona pellucida can be dissolved by proteolytic onzymes such as ficin, papain, 'Pronase' (a baclerial proteinase) and trypsin ${ }^{2,5}$, but the mechanism by which dissolution is brought about in vivo remains obsetre ${ }^{6}$. Thowever, it is known that when spormatozoa penetrate the layers of cumulus and corona cells of rabbit eggs tho acrosomes become detached", and it has boon suggested that this leads to liberation of a 'zona lysin', a hypothetieal enzyme which is localized between the sperm head and the acrosome?

Acrosomes can be dislodged from ram, bull and rabbit spormatozoa by means of anionic detergents and obtained as suspensions which are almost free from any other parts of the sperm cell ${ }^{\beta, 9}$. The separated acrosomes become solubilized, in the form of a lipoglycoprotein complex, following treatment with ethanol'.

When froshly ovulatod rabbit eggs wero incubated at $p \mathrm{H} 7$ and $37^{\circ} \mathrm{C}$ with lipoglycoprotein complex from ram, bull or rabbit spermatozoa the eggs became denudod, that is, cumulus and corona colls were dispersed, In some cases dissolution of the zona pellucida was also observed. When the eggs were stationary in the lipoglycoprotein solution, up to $24 \mathrm{~h}$ was necoganry for full effects to be observed, but with occasional gentle shaking tho process of dentudation occurred more rapidly. Control exporiments without lipoglycoprotein complex showed no denudation. The donuding activity of lipoglycoprotoin complex was much lower after it had been heated to $100^{\circ} \mathrm{C}$. Activity was also decreased by iodoacetate and by the polyanionic hyoluronidase inhibitor $53 D K^{10}$, although with both inhibitors the extent of inhibition varied widely from one preparation to another. The lipoglycoprotoin complex proparations contained some hyaluronidase; but there was no parallolism between denuding activities and hyaluronidase contents. The preparations also showed proteolytic activity, reflected in tho liberation of amino groups, when incubated alone at $p \mathrm{H} \sim 7$. In presence of

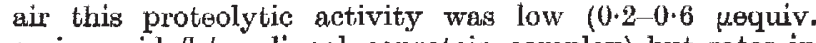
amino-acids $/ \mathrm{h} / \mathrm{mg}$ lipoglycoprotein complox) but rates in absence of oxygen were 2-3 times greater.

The experiments briofy reported hore provide the first demonstrations of a denuding effect on ova, and a dissolution of the zona pellucida, by a cell-free enzyme preparation with proteolytic activity, obtained from mammalian spermatozoa.

P. N. Srivastava

C. E. ADams

E. F. TIARTRER

Agricultural Research Council,

Unit of Reproductive Physiology and Biochemistry, 307 Huntingdon Road, Cambridge.

'Pincus, (t., Proe. Roy. Sot., B, 10\%, 182 (1930).

${ }^{2}$ Yamane, J., Cytologia, 1, 394 (1930).

acClean, D., and Rowlands, I. W., Nature, 150, 627 (1942)

4 Swyer, G. T. M., Nature, 159, 873 (1947). Chang, M. C., Ann. N.Y. Acad.

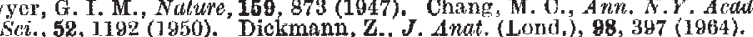

"Braden, A. W. H., A ustral. J. Biol. Sci., 5, 460 (1952), Gwatkin, R. B. T., J. Reprod, Fertil., 7,99 (1964).

- Austin, C. R., The Mammalian Egg (Blackwell, Oxford, 1961).

${ }^{7}$ Austin, C. R., and Bishon, M. W. H., Proc. Roy. Soc., B, 149, 241 (1958).

${ }^{8}$ Hathaway, R. R., und Hartrce, F. F., J. Reprod. Fertil, 5, 225 (1963).

- Hartree, F. F., and srivastava, P. N., J. Reprod, Fertil. (in the press). 10 Parkes, A. S., Rogers, H. J., and Spensley, I'. C., Proc. Soc. Study Fertil.,
6, 65 (1954),

\section{Relationship between Concentrations of Ruminal Nucleic Acids and Exeretion of Purine Derivatives by Sheep}

Purines can bo synthesized in the animal body from glycine, sorine, aspartic aoid, glutamine, formate and respiratory earkon dioxide, but they are also derived from dictary and onllular nucleoprotein. Recont work with cattle ${ }^{i}$ and sheep ${ }^{2}$ has shown that purine derivatives (uric acid and allantoin in urino) are quantitatively important end-products of these ruminants when they are fed on diets with a high-energy, low-protein content and when the animals aro in oither $N$ oquilibrium or slight positive balance. With such dicts protein is utilized very efficiently. It is well known that efficiency of protein utilization in the ruminant depends on the catabolic and synthotic activitios of the rumen micro-organisms. For high efficiency, the brealkdown products of dietary protein and other nitrogenous compounds must be rapidly synthosized into microbial protoin in the rumen ${ }^{3}$. This evidence suggests that most of the allantoin and uric acid exoreted by ruminants may be dorivod from nucleic acids of rumon micro-organisms. Some support for this suggestion has been roported by Blaxter and Martin, who showed that afler ruminal infusion of easein (which is free of purine and pyrimidine bases) slightly more allantoin was excreted than after abomasal infusion of tho same quantity of casein.

In trials briefly described in this communication, the relationship was examined betweon ruminal coneontrations of nucleic acids and the urinary excretion of allantoin and uric anid by sheep which were fitted with rumen cannule and fod on a varioty of low-protein diets.

Sixteen diels, ranging in eruds protein content from approximately 2.6 to 10 por cent and varying in digestible energy content (four lovols) were offered ad lib. to four groups of four fistulated wethor sheep for periods of 28 days (the dotailed composition of the diets and the experimental plan have boen described proviously ${ }^{5}$. In the last week of each 28-day poriod the sheep were housed in metabolism orates and total urinary collections were made. Samples of rumon fluid, approximatcly $50 \mathrm{ml}$. in volume, were taken at 7 a.m., 8 a.m., 9 a.m., 11 a.m. and 4 p.m. during one day of this collection period. The 7 a.m. and 4 p.m. sarrples were withdrawn immodintely before fooding at those timos. The rumen fluid was 